\title{
Hoof capsule distortion and radiographic measurements of the front feet in Mangalarga Marchador horses subjected to athletic training
}

\author{
Bianca Drumond', Antônio Marcos Guimarães Ginelli², Rafael Resende Faleiros ${ }^{3}$, Jessica Fontana de Magalhães ${ }^{4}$ \\ and Clarisse Simóes Coelho ${ }^{5}$ \\ I' Programa de Mestrado em Ciência Animal (Animal Science Master Program), Universidade Vila Velha (UVV-ES), Vila Velha - ES, Brazil \\ 2 Rancho Bela Vista Veterinary Hospital, Serra-ES, Brazil \\ ${ }^{3}$ Escola de Veterinária, Universidade Federal de Minas Gerais (UFMG), Belo Horizonte - MG, Brazil \\ ${ }^{4}$ Programa de Mestrado em Medicina Veterinária, Universidade Federal de Minas Gerais (UFMG), Belo Horizonte - MG, Brazil \\ ${ }^{5}$ Programa de Mestrado em Ciência Animal (Animal Science Master Program), Universidade Vila Velha (UVV-ES), Vila Velha-ES, Brazil
}

\begin{abstract}
Summary: The hooves of Mangalarga Marchador horses, the largest equine breed in Brazil, are commonly trimmed with long toes to create more animation to their typical gait called marcha. With the hypothesis that long toes cause radiographic changes in the feet, which correlate with proximal suspensory ligament dimensions, the aim of this study was to determine radiographic measurements values of front hooves and correlate them with cross sectional area (CSA) values of the proximal suspensory ligament in Mangalarga Marchador horses subjected to athletic training. Two mares and 18 geldings, $3-10$ years of age $(5.8 \pm 2.7$ years old) were used. Both forelimbs were examined radiographically in lateromedial views and measurements of 14 parameters of interest of each foot were obtained with Metron Hoof Pro Software. Ultrasonographic images were obtained from the proximal suspensory ligament at a distance of 4 and $8 \mathrm{~cm}$ from the accessory carpal bone with standard ultrasound technique with the limb in a weight bearing position to determine the CSA. Correlation between hoof and suspensory ligament variables were evaluated using the correlation Pearson test $(P<0.05)$. All horses had a broken back hoof pastern axis, and $59 \%$ of them were found to have underrun heels, indicating a high risk for lameness development. However, no significant correlation between hoof measurements and CSA of the proximal suspensory ligaments was found $(P>0.05)$. Although the effects of long toe trimming could be characterized with hoof radiographic measurements, no evidences of proximal suspensory ligament stress could be detected in this horse population.
\end{abstract}

Keywords: orthopedic / horse / underrun heels / toe support / hoof pastern axis / suspensory desmistis / marcha

Citation: Drumond B., Guimarães Ginelli A. M., Resende Faleiros R., de Magalhães J. F., Simões Coelho C. (2016) Hoof capsule distortion and radiographic measurements of the front feet in Mangalarga Marchador horses subjected to athletic training. Pferdeheiulkunde 32, $110-118$

Correspondence: Clarisse Simões Coelho, Programa de Mestrado em Ciência Animal (Animal Science Master Program), Universidade Vila Velha (UV-ES), Vila Velha-ES, Brazilo E-mail: clarisse.coelho@uvv.br

\section{Introduction}

Hoof related lameness is common in performance and pleasure horses (O'Grady and Poupard 2001) and foot conformation may be related with performance (Kobluc et al. 1989). Clinical studies have focused on the importance of foot conformation and balance as a risk factor for musculoskeletal injury (O'Grady and Poupard 2001, Anderson and Mcllwraith 2004). Conformation is the static relation and can refer to the limb or the whole animal, whereas balance is the static and dynamic relation for an optical functioning of the foot (Hill et al. 2004, Kummer et al. 2005).

Foot conformation influences biomechanical function and there are hoof conformations that are hypothesized to be predisposing factors to lameness (Parks 2003, Holroyd et al. 2013). Anderson and Mcllwraith (2004) has shown that deep digital flexor tendon strain decreased as toe angle increased from $55-78^{\circ}$ and strain of the extensor branch of the suspensory ligament increased rapidly when toe angle increased. Crevier-Denoix et al. (2001) found similar results, with increase in strain on the suspensory ligament with heal elevation and decrease with toe elevation. When an egg-bar shoe was applied to ponies, the mean peak strain in the deep digital flexor tendon was $0.13 \%$ lower and strain in the suspensory ligament was $0.22 \%$ higher than when barefoot (Riemersma et al. 1996). Another study showed that hoof growth between two shoeing sessions at an 8-week interval caused an increase in extension of the distal interphalangeal joint (Moleman et al. 2006). Furthermore, Dyson (2007) states that pain in the foot can be found with desmitis of the proximal suspensory ligament and feet should be evaluated carefully when treating horses with suspensory desmitis because hoof imbalance is a predisposing factor for this type of injury.

The hooves of Mangalarga Marchador horses are commonly trimmed with long toes to create more animation to their typical gait called marcha (Magalhães et al. 2015). The effect of this trim has caused a high level of discussion in the past as it predisposes to low heels and broken back pastern hoof angles resulting in a hoof capsule distortion condition named underrun or low heels (Hunt 2012). Horses with low heels and long toes appear to be prone to toe first landing, the normal foot-loading pattern is out of sequence. In a toe first landing pattern the toe would impact the ground, then as the body passes over the limb the heel rocks backward as the fetlock descends downward increasing stress on the suspensory ligament (Wilson et al. 2001, Morrison 2015). Additionally, the ocurrence of underrun heel has been associated with cat- 
astrophic suspensory apparatus injuries in racehorses (Balch et al. 2002).

Long toes in Mangalarga Marchador horses can predispose to feet imbalance, which interferes with proximal suspensory ligament dimensions due to stress. With this hypotheses, the aim of this study was to determine radiographic measurement values of front hooves and correlate them with cross sectional area (CSA) values of the proximal suspensory ligament in Mangalarga Marchador horses subjected to athletic training.

\section{Material and Methods}

Horses

A total of 20 Mangalarga Marchador horses were used, two mares and 18 geldings, $3-10$ years of age $(5.8 \pm 2.7$ years old), with a height at the withers ranging from 1.42 to $1.58 \mathrm{~m}(1.50 \pm 0.04 \mathrm{~m})$, a bodyweight of 370 to $430 \mathrm{~kg}$ $(372.5 \pm 36.2 \mathrm{~kg})$ and a body mass index $(\mathrm{BMI}=$ body weight $(\mathrm{kg}) /[$ height at the withers $(\mathrm{m})]) 2$ of 132.03 to $191.11 \mathrm{~kg} / \mathrm{m}^{2}\left(164.77 \pm 12.74 \mathrm{~kg} / \mathrm{m}^{2}\right)$. All the horses were clinically examined by a clinician experienced in lameness prior to radiographic exams and ultrasonographic assessment and only sound animals without perceivable lameness were included in this study. During veterinarian examination a special focus was put on the tendon and ligaments in the metacarpal region and the hooves of the forelimbs. The structures were palpated in a weight bearing as well as in a flexed position and the feet showed no abnormalities. All the horses included in this study were in training for at least six months. Training consisted of a 60-minutes walking without a rider, twice a week, alternating with a 30-40 minutes of marcha with rider on other three days. On weekends animals were submitted to a 20 minutes period of marcha gait with rider on each day. The horses were from 9 different properties all in the limit of $50 \mathrm{~km}$ and with similar management practices being trimmed in the interval of 6 weeks approximately. 17 of the horses were using standard shoes at the time of the experiment, which weren't removed at any time during examination.
Radiographic method

The horses were positioned with both forelimbs simultaneously on a wooden block, both limbs perpendicular to the ground and with equal weight bearing (Kummer et al. 2006). Lateromedial radiographs at a standardized known distance $(80 \mathrm{~cm})$ with a digital X-ray unit (DR Leonardo/Macrotec) were performed. The horizontal x-ray beam was centered $2 \mathrm{~cm}$ below the coronary band, at the midpoint between the bulbs of the heel and the proximodorsal aspect of the hoof wall. A radiopaque marker of known length $(9.2 \mathrm{~cm})$ to delineate the dorsal hoof wall was taped onto the hoof wall bordering the hair line. The foot to be radiographed was placed in such a manner as to ensure that the vertically positioned cassette touched the hoof capsule on the medial side. The exposure factors for lateromedial views were $70 \mathrm{kV}$ and $8 \mathrm{mAs}$.

The images were evaluated and measured individually for each limb using the Metron Hoof Pro software (Epona Tech LLC Version 6.06). The measurements were done in partnership with Universidade Federal de Minas Gerais (UFMG). Fourteen parameters (Figure 1) measured on the lateromedial view were: foot pastern axis, heel angle, founder distance, third phalanx (P3) to toe (toe length), length of the second phalanx (LP2), P3 palmar angle, toe support (Figure 2), sole thickness, coffin joint angle (JA3) (Figure 3), pastern joint angle (JA2), heel height, hoof angle (Figure 4), proximal (HP3P) and distal (HP3D) distance from P3 to dorsal hoof wall (Figure 5). Hooves were considered to have underrun heel when the angle of the heel was 5 or more degrees lower than the angle of the toe (Turner and Stork 1988). Horses were considered to have a broken back hoof pastern axis when at least one of their front hooves had a foot pastern axis less than $180^{\circ}$.

\section{Ultrasonography}

The horses were prepared for the examination by clipping the hair over the palmar metacarpal region from the distal aspect of the accessory carpal bone (ACB) for $8 \mathrm{~cm}$ distally. The legs were marked at the lateral aspect of the clipped area with a plastic surgery marker crayon (DERMATOGRAPH/MITSU-BIS$\mathrm{HI} * 7600)$ at two regions of interest (ROI), 4 and $8 \mathrm{~cm}$ distal

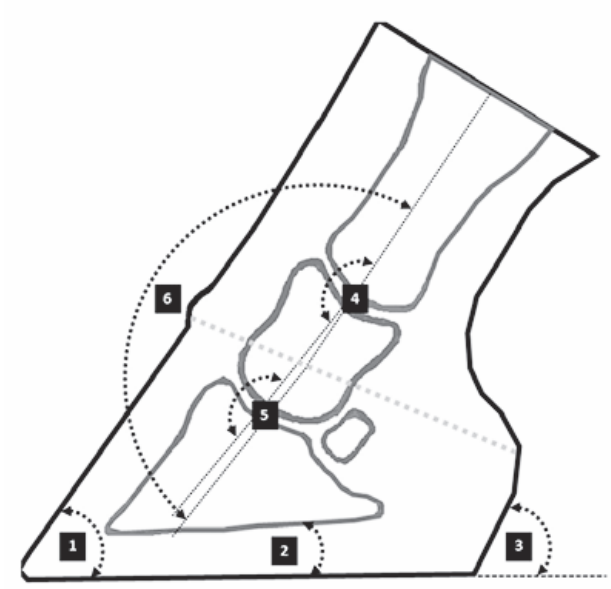
1. Hoof angle
2. P3 palmar angle
3. Heel angle
4. JA2
5. $\mathrm{JA} 3$
6. Hoof pastern axis
7. Toe support
8. P3 to toe
9. Sole thickness
10. HP3D
11. HP3P
12. Founder distance
13. LP2 length

14. Heel hight

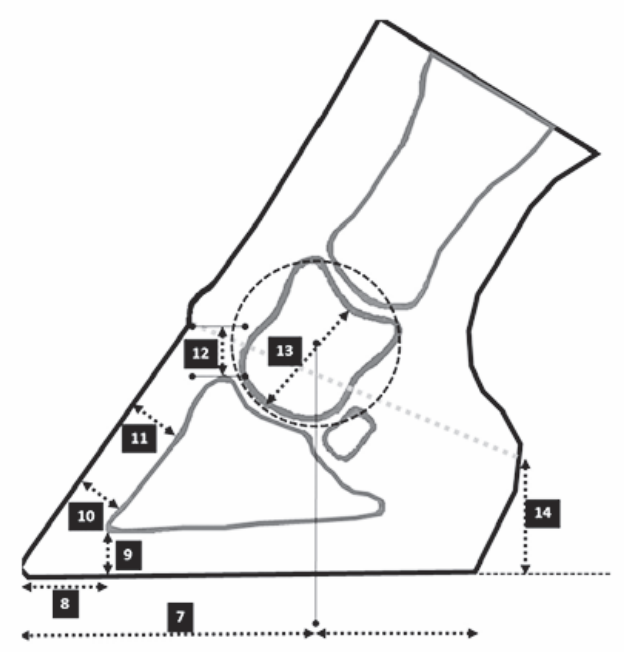

Fig. 1 Schematic lateromedial view of the 14 measured parameters. | Schematische lateromediale Darstellung der 14 gemessenen Parameter 


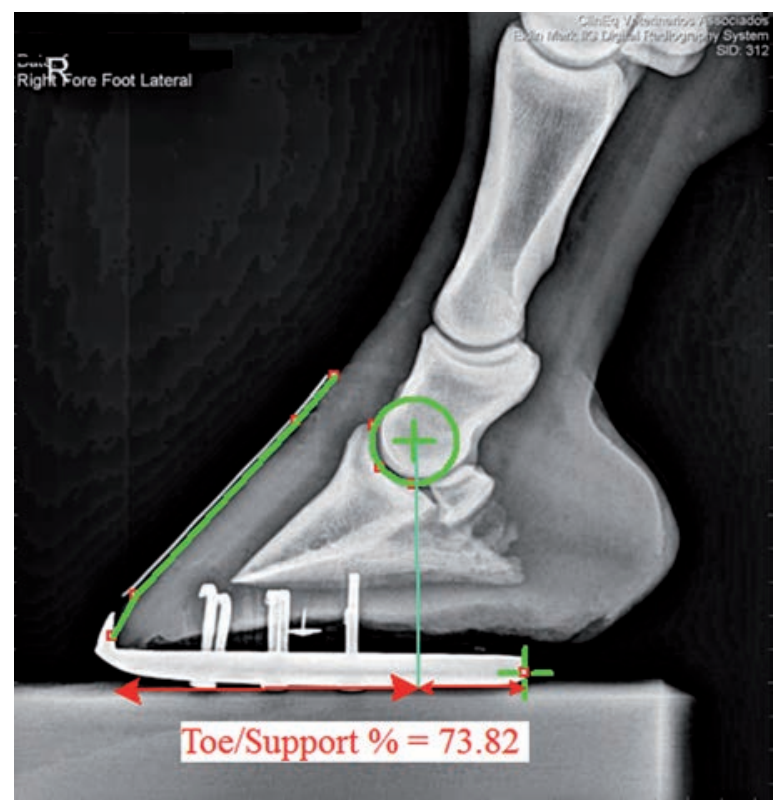

Fig. 2 Radiograph method used for measuring toe support. Radiographische Methode, um "toe support" zu messen.

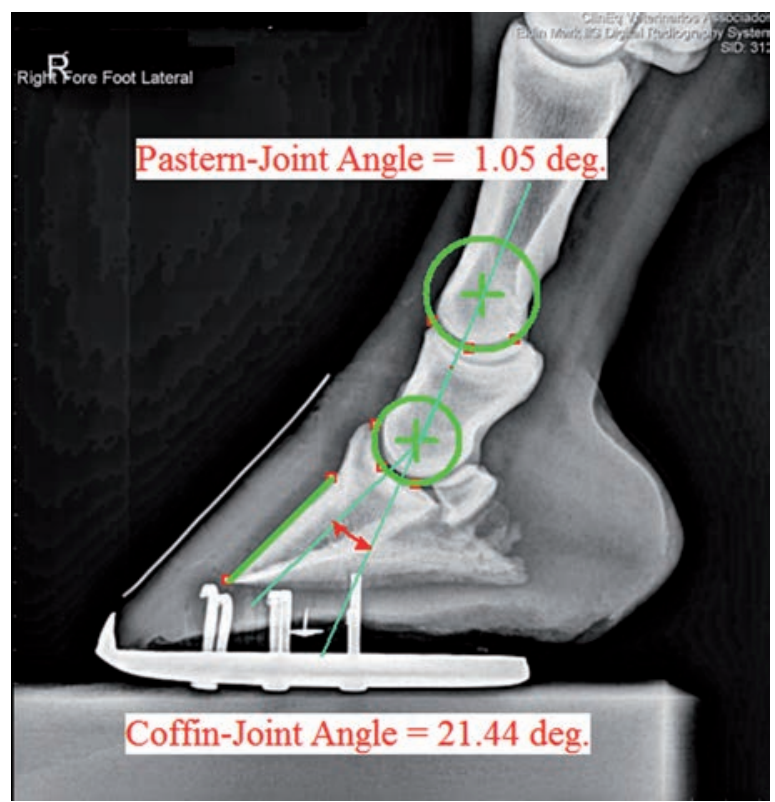

Fig. 3 Radiographic method for measuring JA2 and JA3. The value of the coffin-joint angle is the geometric angle formed between a constructed line from the rotation center associated with the coffin joint extending down towards the sole and a line defined by connecting the two rotation centers. | Radiographische Methode, um JA2 und JA3 zu bestimmen. Die Größe des Hufgelenkwinkels ist der geometrische Winkel zwischen einer imaginären Linie des Rotationszentrums des Hufgelenks bis zum Boden und einer imaginären Linie durch beide Rotationszentren.

to the ACB. After this, the clipped area was washed with water to enhance the ultrasonographic acoustic coupling. Ultrasound gel (RMC/ANVISA register n0 80122200001) was applied to the area to be examined.

The ultrasonographic examination of all horses was performed by one operator to exclude the possibility of inter-operator variations using a portable ultrasound machine (DP50 Mindray) with a $7.5 \mathrm{MHz}$ linear probe and a standoff pad. Ultrasound images were obtained at two ROI. Transverse

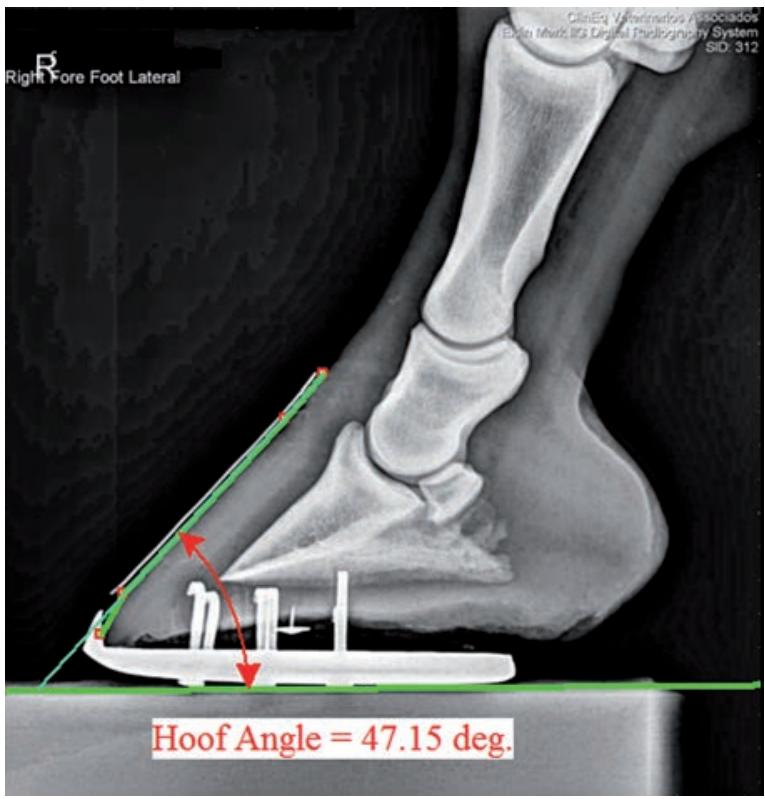

Fig. 4 Radiographic method for measuring the hoof angle. Radiographische Methode, um den Hufwinkel zu bestimmen.

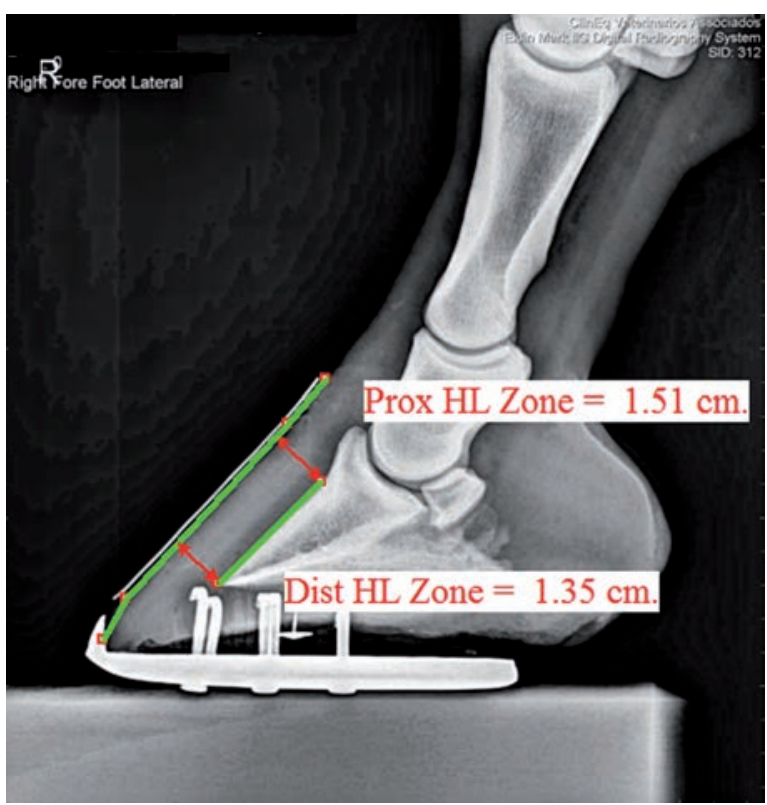

Fig. 5 Radiographic method for measuring HP3P and HP3D. Radiographische Methode, um HP3P und HP3D zu bestimmen

images were obtained with the ultrasound beam placed perpendicular to the ligament fibers using the standard ultrasound technique with the limb in a weight bearing position (Figure 6). All the images were obtained three times for each $\mathrm{ROI}$. Cross sectional area $\left(\mathrm{CSA} ; \mathrm{cm}^{2}\right)$ of the suspensory ligament was measured using the ultrasound software according to (Boehart et al. 2010).

\section{Precision measurements}

To determine the intra-operator variation, the left forelimb of one 3-year-old stallion was examined. Following preparation as described above for ultrasound examination, each structure was imaged eight times at every $\mathrm{ROI}$ to determine the coefficient of variation (CV). For radiographic measurements each 
parameter was measured eight times in one radiograph to determine the coefficient of variation.

\section{Statistical analysis}

The prevalence of underrun heel and broken back hoof pastern axis were expressed in percentage of affected horses. Other results are expressed as the mean values and standard deviation calculated using General Linear Models procedure of SAS (SAS for Windows, Version 9.2, Cary, NC). We studied the effects of laterality (comparing measurements obtained for the left and right forelimbs). Differences in individual mean values were analysed through pair-wise comparisons

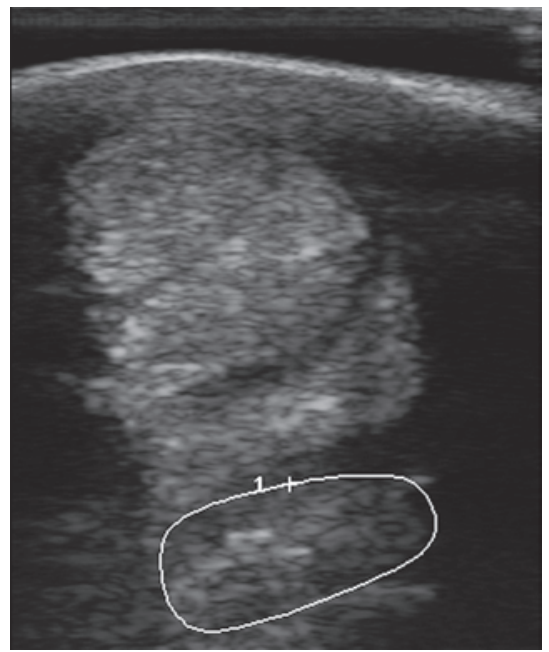

Fig. 6 Cross sectional area (CSA) of the proximal suspensory ligament measured $8 \mathrm{~cm}$ from the accessory carpal bone. | Schnittfläche des Fesselträgerursprungs gemessen $8 \mathrm{~cm}$ des Os carpi accessorium (probability of difference analysis [PDIFF]; SAS Institute Inc.). Results were considered significante if $\mathrm{P}<0.05$.

Correlations between CSA of proximal suspensory ligaments and specific hoof measurements (foot pastern axis, heel angle, P3 to toe, toe support, JA3, JA2, heel height, hoof angle) for each side (right or left) were analyzed by Pearson Correlations using CORR procedure of the Statistical Analysis System (SAS ${ }^{\circledR}$ 9.2, SAS Inst., Cary, NC, USA). Strong correlation occurs when $r$ is near 0.9 and $P<0.05$.

\section{Results}

Table 1 shows the mean values and standard deviations of transverse measurements derived from the standard ultrasound technique of suspensory ligament and 14 parameters obtained on lateromedial radiographic view, including $P$ values from comparison between these measurements obtained for the right and left forelimbs. No correlation was found between hoof measurements and CSA of proximal suspensory ligaments (Table 2$)(P>0.05)$.

The CVs for ultrasonographic measurements ranged from $2.3 \%$ to $3.0 \%$. The $\mathrm{CVs}$ for radiographic measurements ranged from $0.7 \%$ to $5.7 \%$ except for the following angles. The P3 palmar angle and JA3 showed CVs of $49.7 \%$ and $505.6 \%$ respectively.

\section{Discussion}

To the best of the authors knowledge, this is the first study to investigate hoof balance by evaluating feet radiographic characteristics of Mangalarga Marchador horses in athletic trai-

Table 1 Mean values \pm standard deviation of CSA of proximal suspensory ligaments and 14 parameters obtained on lateromedial radiographic view of 20 Mangalarga Marchador horses, including P values from comparison between these measurements obtained for the right and left forelimbs.

\begin{tabular}{|c|c|c|c|}
\hline Parameters & Right Forelimb & Left Forelimb & $\mathrm{P}$ \\
\hline Proximal suspensory ligament $\left(\mathrm{cm}^{2}\right)-4 \mathrm{~cm}$ distance & $0.99 \pm 0.12$ & $0.97 \pm 0.11$ & 0.6254 \\
\hline Proximal suspensory ligament $\left(\mathrm{cm}^{2}\right)-8 \mathrm{~cm}$ distance & $0.93 \pm 0.09$ & $0.97 \pm 0.13$ & 0.1764 \\
\hline P3 to toe $(\mathrm{cm})$ & $4.5 \pm 0.9$ & $4.5 \pm 0.8$ & 0.9571 \\
\hline Heel hight $(\mathrm{cm})$ & $6.8 \pm 0.7$ & $7.0 \pm 0.7$ & 0.9006 \\
\hline Heel angle $\left({ }^{\circ}\right)$ & $46.9 \pm 9.0$ & $42.9 \pm 6.3$ & 0.0118 \\
\hline Hoof pastern axis $\left({ }^{\circ}\right)$ & $159.6 \pm 8.9$ & $162.8 \pm 6.6$ & 0.0468 \\
\hline P3 palmar angle $\left({ }^{\circ}\right)$ & $4.6 \pm 4.1$ & $5.1 \pm 3.2$ & 0.2556 \\
\hline Founder distance $(\mathrm{cm})$ & $1.0 \pm 0.3$ & $1.2 \pm 0.4$ & 0.8508 \\
\hline Sole thickness $(\mathrm{cm})$ & $2.6 \pm 0.6$ & $2.6 \pm 0.6$ & 0.8837 \\
\hline Hoof angle $\left({ }^{\circ}\right)$ & $47.4 \pm 4.2$ & $48.8 \pm 4.2$ & 0.3666 \\
\hline $\operatorname{HP3P}\left({ }^{\circ}\right)$ & $2.0 \pm 0.2$ & $2.2 \pm 0.3$ & 0.7619 \\
\hline HP3D $\left({ }^{\circ}\right)$ & $2.0 \pm 0.3$ & $2.0 \pm 0.3$ & 0.9334 \\
\hline Toe support (\%) & $74.2 \pm 6.7$ & $72.6 \pm 5.6$ & 0.2902 \\
\hline JA2 $\left(^{\circ}\right)$ & $3.5 \pm 5.2$ & $4.3 \pm 4.1$ & 0.6238 \\
\hline JA3 $\left(^{\circ}\right)$ & $13.1 \pm 6.7$ & $14.3 \pm 7.1$ & 0.4386 \\
\hline LP2 $(\mathrm{cm})$ & $4.8 \pm 0.3$ & $4.8 \pm 0.3$ & 0.9917 \\
\hline
\end{tabular}

P3, third phalanx; HP3P, hoof p3 distance proximal; HP3D, hoof p3 distance distal; JA2, pastern joint angle; JA3, coffin joint joint angle. Numbers in bold represent $P$ values to be statistically significant $(P<0.05)$. 
ning for marcha competitions. The long toe trimming was characterized by the long toe length $(4.5 \pm 0.9 \mathrm{~cm})$ in these horses. The possible effects of these long trimming were also detected as all horses had a broken back hoof pastern axis (mean \pm SD pastern hoof angle was $161 \pm 80$ ) and $59 \%$ of them have underrun heels. Also, the mean toe support was $76.4 \pm 6 \%$.

The measurement of toe length of the hoof can be of interest to decide how much toe can be trimmed (Craig et al. 2001). The results found here are higher than the ones described by Kummer et al. (2006) for Thoroughbreds $(3.1-3.2 \mathrm{~cm}$ ) and this can be explained by the common practice of growing the toes longer in Mangalarga Marchador horses. Due to the results seen in this study they can be prone to injury in the deep digital flexor tendon and podotrochlear syndrome.

The foot pastern axis is one of the most accepted measurements to evaluate foot balance (O'Grady and Poupard 2003). The angle formed by the dorsal hoof wall and by the pastern with the ground should be the same, creating an angle of 180 degrees between them (Parks 2003). When the angle of the dorsal hoof wall is lower than the angle of the dorsal pastern there is a broken-back hoof pastern axis. This type of foot configuration, which was totally prevalent in this Mangalarga Marchador horse population, is believed to be caused by the underrun heels capsule distortion when the toe is allowed to grow excessively long and the heels grow forward causing the pastern to move forward (O'Grady and Poupard 2003).

Underrun heels are the most commonly encountered hoof abnormality in lame horses and was found in $77 \%$ of the hor- ses with foot related lameness (Turner 1986). As the angle of the heels decreases, the compromised horn tubules lose the ability to support weight overloading the frog, deep digital flexor tendon (DDFT), and digital cushion and ultimately causing pain on the heel area (O'Grady and Poupard 2003). Hoof wall separations, quarter and heel cracks are common findings in underrun heels. Additionally, horses with low heels and long toes develop toe first landing, which bypasses the heel's shock absorbing function and increases strain on the deep digital flexor tendon and navicular apparatus (Morrison 2015).

Furthermore, the long toe creates a longer moment arm during breakover phase causing further tension on the deep digital flexor tendon and leading the lamina to stretch. The laminar stress together with toe first landing predisposes to white line widening, decreasing protection and allowing easier penetration of organisms (O'Grady 2008). Taking together, our findings indicate that this population of Mangalarga Marchador horses have a high prevalence of hoof capsule distortions and are at high risk to develop lameness.

Another way to demonstrate the hoof pastern axis is by measuring the JA2 and JA3. This technique offers a reliable way for practitioners to communicate regarding conformation of the equine digit (Craig et al. 2001). The literature states that these angles should be around 0 for the real alignment of the phalanx (Stashak et al. 2002). However, in a study with 151 forelimbs of several breeds the mean values found were $5.8 \pm 5.2^{\circ}$ and $8.3 \pm 9.0^{\circ}$ for JA2 and JA3, respectively (Craig et al. 2005). Results in this study differ from the ones above, with a much higher JA3 and a lower JA2. It has been shown that the ground reaction force moves toward the heels

Table 2 Correlations between CSA of proximal suspensory ligaments and hoof measurements (foot pastern axis, heel angle, P3 to toe, toe support, JA3, JA2, heel height, hoof angle, distance of the hoof from fetlock) for the right and left forelimbs of 20 Mangalarga Marchador horses.

\begin{tabular}{|c|c|c|c|c|c|}
\hline \multirow{2}{*}{\multicolumn{2}{|c|}{ Parameters }} & \multicolumn{2}{|c|}{ Proximal suspensory ligament - $4 \mathrm{~cm}$ distance } & \multicolumn{2}{|c|}{ Proximal suspensory ligament - $8 \mathrm{~cm}$ distance } \\
\hline & & Right & Left & Right & Left \\
\hline \multirow{2}{*}{ P3 to toe } & Right & $r=0.2867 p=0.2204$ & & $r=0.0485 p=0.8392$ & \\
\hline & Left & & $r=-0.2198 p=0.3517$ & & $r=0.2681 p=0.2530$ \\
\hline \multirow{2}{*}{ Heel height } & Right & $r=0.2361 p=0.3163$ & & $r=-0.1631 p=0.4921$ & \\
\hline & Left & & $r=0.0380 p=0.8736$ & & $r=0.1110 p=0.6414$ \\
\hline \multirow{2}{*}{ Hoof to fetlock } & Right & $r=-0.2810 p=0.2301$ & & $r=-0.3509 p=0.1293$ & \\
\hline & Left & & $r=0.1007 p=0.7106$ & & $r=-0.0218 p=0.9361$ \\
\hline \multirow{2}{*}{ Heel angle } & Right & $r=-0.1062 p=0.6559$ & & $r=-0.0668 p=0.7797$ & \\
\hline & Left & & $r=-0.2556 p=0.2767$ & & $r=-0.3628 p=0.1159$ \\
\hline \multirow{2}{*}{$\begin{array}{c}\text { Hoof pastern } \\
\text { axis }\end{array}$} & Right & $r=-0.2585 p=0.2711$ & & $r=-0.2125 p=0.3683$ & \\
\hline & Left & & $r=0.1292 p=0.5871$ & & $r=-0.1421 p=0.5502$ \\
\hline \multirow{2}{*}{ Hoof angle } & Right & $r=-0.2261 p=0.3379$ & & $r=0.0173 p=0.9424$ & \\
\hline & Left & & $r=0.3080 p=0.1865$ & & $r=-0.2167 p=0.3588$ \\
\hline \multirow{2}{*}{ Toe support } & Right & $r=0.1323 p=0.5783$ & & $r=0.1144 p=0.6312$ & \\
\hline & Left & & $r=-0.1396 p=0.5574$ & & $r=0.0973 p=0.6834$ \\
\hline \multirow{2}{*}{ JA2 } & Right & $r=0.1723 p=0.4678$ & & $r=0.3404 p=0.1420$ & \\
\hline & Left & & $r=0.0141 p=0.9531$ & & $r=0.0243 p=0.9192$ \\
\hline \multirow{2}{*}{ JA3 } & Right & $r=0.1017 p=0.6696$ & & $r=0.3035 p=0.1933$ & \\
\hline & Left & & $r=-0.1626 p=0.4935$ & & $r=-0.0041 p=0.9863$ \\
\hline
\end{tabular}

P3 to toe, third phalanx (P3) to toe; JA2, pastern joint angle; JA3, coffin joint angle. Strong correlation occurs when $r$ is near 0.9 and $p<0.05$ by Pearson correlation 
between two showing intervals leading to an extension of the distal interphalangeal joint, increasing tension on the deep digital flexor tendon and additional pressure on the navicular bursa (Moleman et al. 2006).

O'Grady and Poupard (2001) suggest that the toe support percentage is ideally $50 \%$, but in a recent study with 131 forelimbs of different horse breeds a mean value of $67.06 \pm 5.41 \%$ was found, and none of these animals presented toe support of $50 \%$ (Craig et al. 2001). The results of this study are even higher, which can also be explained by a strong tendency in Mangalarga Marchador horses to be trimmed with a longer toe with the goal to create more animation to the marcha gait (Magalhães et al. 2014).

There are a lot of opinions on what is considered normal for dorsal hoof wall angle measurement. Most authors agree that a $45-55^{\circ}$ and $50-55^{\circ}$ angle is considered normal for front and hind limbs respectively, similar to the values shown in this study for forelimbs (Bach et al. 1995). However, these values may not consider individual conformation (O'Grady and Poupard 2001). According to these authors, the ideal angle occurs when a line drawn at the dorsal hoof wall is equivalent with a line drawn at the heels, and so presenting the same angle (O'Grady and Poupard 2001). In this study, heel angle was lower than hoof angle, corroborating with researchers that claim that this equivalence is hard to achieve when the wall at the heels are thin and flexible what leads to a higher load when compared to the toe (Parks 2003, O'Grady 2008, Dyson et al. 2011 ). In racehorses, Anderson and Mcll/wraith (2004) found a mean value of 48 degrees for dorsal hoof wall angle in 3-year-old horses. Kobluc et al. (1989) showed mean values between 50 and 54.6 degrees in 95 racehorses. Hampson et al. (2013) found mean values of $52.8 \pm 2.6$ degrees for ferral horses, which are higher than the ones seen in this study.

The results seen in this study for HP3P and HP3D are in agreement with Redden (2003) that states that in the foot of healthy adult horses this distance is similar for proximal and distal measurements. In immature feet, the HP3P can be higher than HP3D (Redden 2003). The values found here are higher than Quarter horse and Thoroughbred reference values 1.5 to $1.6 \mathrm{~cm}$ (Redden 2003). A study with Warmblood horses found values that range from 1.8 to $1.9 \mathrm{~cm}$ (Kummer et al. 2006). Furthermore, Pollitt (2008) stated that this distance should be in between $1.6 \mathrm{~cm}$ to $1.8 \mathrm{~cm}$ in horses with mean weight of 400 to $450 \mathrm{~kg}$. In another study with Mangalarga Marchador horses similar values were found, $2.05 \pm 0.185 \mathrm{~cm}$ for HP3P and $1.89 \pm 0.189 \mathrm{~cm}$ for HP3D (Magalhães et al. 2014). This measurement has an important value in horses at early stage of laminitis, white line disease and other conditions, when HP3D is higher than HP3P (Redden 2003). Considering the discussion above about the high prevalence of long toes and underrun heels, higher HP3D lengths in Mangalarga Marchador horses could also be related to white line widening observed in these conditions.

Founder distance is a parameter described by Cripps and Eustace (1999) and it is considered an important measurement referent to laminitis. This distance should be lower than $1.0 \mathrm{~cm}$ (Eustace 2010) or $1.1 \mathrm{~cm}$ (Redden 1997). The measurements in the current study were slightly greater. Similar results were found by Magalhães et al. (2014) for 36 Mangalarga Marchador horses, recording values of $1.18 \pm 0.326$ $\mathrm{cm}$. Furthermore, these authors claim that values in this breed should be evaluated with caution when compared to previously reported values because they seem to be higher in horses with no sign of laminitis. Warmblood horses showed mean values that range from $1.0 \pm 0.35$ to $1.1 \pm 0.34 \mathrm{~cm}$ (Redden 2003, Kummer et al. 2006). The large variability of this measurement indicates that it is only of limited usefulness in the early stages of laminitis and most valuable when measured on sequential radiographs (Kummer et al. 2006).

According to O'Grady (2008), the ideal sole thickness is of $1,5 \mathrm{~cm}$. However, there have been different mean values found for Thoroughbreds, $0.8 \mathrm{~cm}$ or less, which may lead them to be predisposed to sole bruising. The results seen in this study are higher than in other breeds (Kummer et al. 2006, Foor 2007), which suggests that these horses are less likely to suffer from sole bruising. This theory is supported by clinical experience with this horse breed.

The results seen in this research for P3 palmar angle are in agreement with $O^{\prime}$ Grady (2008) which claims that the angle between the palmar surface of P3 and the ground should be $3^{\circ}$ to $5^{\circ}$. A high palmar angle can be found in horses with club foot conformation, laminitis and other pathological conditions. It is important to recognize that 3 horses in this study had negative palmar angles, which means that the palmar process of P3 was lower than the toe. This leads to a significant loss of integrity of the heel area with an increase in strain of the deep digital flexor tendon (Redden 2003).

The heel height was also measured, with values much higher than the ones found by Evaristo et al. (2006) for the same breed, $3.27 \pm 0.55 \mathrm{~cm}$. This difference is probably due to the different technique used. The heel height is normally measured from the ground to the coronet at the heels (Foor 2007) but the identification of the coronet wasn't used in this study, considering the whole palmar region of the foot.

It is known that a diagonal asymmetry pattern whereby the foals position in uterus determines its future conformation (Perreaux and Hagen 2002) and that 70-80\% of the horses are lefthanded (Meij and Meij 1980, Perreaux and Hagen 2002). The differences seen in this study for the parameters evaluated when comparing left and right forelimbs were a higher heel angle and a lower hoof pastern axis on the right forelimb. The higher heel angle corroborates with Perreaux and Hagen (2002) statement, in which the smaller foot, usually the right one, grows faster at the heels, creating a larger heel angle. These facts, added to subclinical pathologies, the influence of the individual body conformation and lack of standardized farrier programs can contribute to the differences seen in this study. More parameters should be evaluated to state that these horses are left-handed.

There is evidence that suspensory ligament CSA increases with training (Çelimli et al. 2004) and biomechanics of the foot can change the strain imposed to it (Dyhre-Poulsen et al. 1994, Degeurce et al. 2001). Further studies are needed to determine the ideal balance for the breed studied and its effects on soft tissues. According to Bischofberger et al. (2006) there is a substantial difference between ultrasonogra- 
phic image of proximal suspensory ligament and magnetic resonance imaging or post mortem histological section. In this study we imaged the same area 8 times to determine the intra-operator variation. On the other side, it has been shown that standard ultrasonography of the proximal suspensory ligament when compared to histology only showed significant differences at $6 \mathrm{~cm}$ from the carpometacarpal joint and didn't show any differences when compared to magnetic resonance imaging (Werpy et al. 2013). Therefore, there are different studies and results on the subject and this study does have limitations.

\section{Conclusion}

Long toe trimming was characterized by the long toe length and was considered to be associated with a high prevalence of broken back hoof pastern axis and underrun heels in training Mangalarga Marchador horses. No evidence of stress in the proximal suspensory ligament could be detected in this horse population. However, this population was considered to be at high risk for lameness development. Other studies are warranted in order to investigate the effects of these hoof conditions in other structures of the suspensory apparatus.

\section{Acknowledgement}

FAPES for master's scholarship of Bianca Drumond.

\section{Animal welfare statement}

The project was approved by the Ethics Committee for Animal Use at Universidade Vila Velha (CEUA-UVV), Protocol $314 / 2014$.

\section{References}

Anderson T. M., Mcllwraith C. W., Douay P. (2004) The role of conformation in musculoskeletal problems in the racing thoroughbred. Equine Vet. J. 36, 571-575

Bach O., Butler D., White K., Metcalf S. (1995) Hoof balance and lameness: improper toe length, hoof angle, and mediolateral balance. Comp. Cont. Educ. Pract. Vet. 17, 1275-1282

Balch O. K., Helman R. G., Collier M. A. (2002) Underrun heels and toe-grab length as possible risk factors for catastrophic musculoskeletal injuries in Oklahoma racehorses. In: Proceedings Anu. Conv. Am. Assoc. Equine Pract. 47, 334-338

Bischofberger A. S., Konar M., Ohlerth S., Geyer H., Lang J., Uletschi G., Lischer C. J. (2006) Magnetic resonance imaging, ultrasonography and histology of the suspensory ligament origin: a comparative study of normal anatomy of Warmblood horses. Equine Vet. J. 38, 508-516

Boehart S., Arndt G., Carstanien B. (2010) Ultrasonographic morphometric measurements of digital flexor tendons and ligaments of the palmar metacarpal region in Haflinger horses. Anat. Histol. Embyol. 39, 366-375

Çelimli N., Seyrek-intas D., Kaya M. (2004) Morphometric measurements of flexor tendons and ligaments in Arabian horses by ultrasonographic examination and comparison with other breeds. Equine Vet. Educ. 16, 81-85

Craig J. J., Craig M. F., Savoldi M. T., Waldsmith J. K. (2005) Locating rotation centers of the equine digit and their use in quantifying conformation. Retrieved from http://www.eponashoe.com/documents/RotationCenters.pdf
Craig J. J., Craig M. F., Weltner T. N. (2001) Quantifying conformation of the equine digit from lateromedial radiographs. In: Proceedings AESM Meeting Conference, 20-25

Crevier-Denoix N., Roosen C., Dardillat C., Pourcelot P., Jerbi H., Saana M., Denoix J. M. (2001) Effects of heel and toe elevation upon the digital joint angles in the standing horse. Equine Vet. J. 33, 74-78

Cripps P. J., Eustace R. A. (1999) Radiological measurements from the feet of normal horses with relevance to laminitis. Equine Vet. J. $31,427-432$

Degeurce C., Chaetau H., Jerbi H., Crevier-Denoix N., Pourcelot P., Audigie F., Pasqui-Boutard V., Geiger D., Denoix J. M. (2001) Three dimensional kinematics of the proximal interphalangeal joint: effects of raising the heels or the toe. Equine Vet. J. Suppl. 33, 79-83

Dyhre-Poulsen P., Smedegaard H. H., Roed J., Korsgaard E. (1994) Equine hoof function investigated by pressure transducers inside the hoof and accelerometers mounted on the first phalanx. Equine Vet. J. 26, 362-366

Dyson S., Arthur R. M., Palmer S. E., Richardson D. (1995) Suspensory ligament desmitis. Vet. Clin. North Am. Equine Pract. 11, $177-215$

Dyson S. (2007) Diagnosis and management of common suspensory lesions in the forelimbs and hindlimbs of sport horses. Clin. Tech. Equine Pract. 6, 179-188.

Dyson S. J., Tranquille C. A., Collins S. N., Parkin T. D. H., Murray R. C. (2011) An investigation of the relationships between angles and shapes of the hoof capsule and the distal phalanx. Equine Vet. J. 43, 295-301

Eustace R. A. (2010) Clinical presentation, diagnoses and prognosis of chronic laminitis in Europe. Vet. Clin. North Am. Equine Pract. 26, 391-405

Evaristo I. G. B., Mielo UP. ,. Ferreira C., Palhares M. S., Calonge D. F., Martins R. A. (2006) Avaliação do equilíbrio médio-lateral do casco de equinos da raça Mangalarga Marchador. Rev. Univ. Rural 26, 121-122

Foor D. (2007) Balancing and shoeing the equine foot. In: Floyd A, Mansmann RA, editors. Equine podiatry, Philadelphia: Saunders Elsevier, 2-40.

Hampson B. A., De Laat M. A., Mills P. C., Pollitt C. C. (2013) The feral horse foot. Part A: observational study of the effect of environment on the morphometrics of the feet of 100 Australian feral horses. Aust. Vet. J. 91, 14-22

Hill A. E., Gardner I. A., Carpenter T. E., Stover S. M. (2004) Effects of injury to the suspensory apparatus, exercise, and horseshoe characteristics on the risk of lateral condylar fracture and suspensory apparatus failure in forelimbs of thoroughbred racehorses. Am. J. Vet. Res. 65, 1508-1517

Holroyd K., Dixon J. J., Mair T., Bolas N., Bolt D. M., David F. (2013) Variation in foot conformation in lame horses with different foot lesions. Vet. J. 195, 361-365

Hunt R. J. (2012) Farriery for the hoof with low or underrun heels. Vet. Clin. North Am. Equine Pract. 28, 351-364

Kobluc C., Robinson R., Gordon B., Clanton C. J., Trent A. M., Ames T. R. (1989) The effect of conformation and shoeing: a cohort study of 95 Thoroughbred racehorses. In: Proceedings AAEP Congress, 259-274

Kummer M., Geyer H., Imboden I., Auer J., Lischer C. (2006) The effect of hoof trimming on radiographic measurements of the front feet of normal Warmblood horses. Vet. J. 172, 58-66

Linford R. L., O Brien T. R., Trout D. R. (1993) Qualitative and morphometric radiographic findings in the distal phalanx and digital soft tissues of sound Thoroughbred racehorses. Am. J. Vet. Res. 54, 38-51

Magalhães J. F., Lima I. R., Lima L. R., Varela J. A. R. C., Vieira R. A. M., Alves G., Faleiros R. R. (2014) Estudo da correlação de medidas radiográficas indicadoras de laminite em éguas da raça Mangalarga Marchador com e sem sinais de sobrepeso. Arq. Bras. Med. Vet. Zootec. 66, 1123-1132

Meij H. S., Meij J. C. P. (1980) Functional asymmetry in the motor system of the horse. S. Afr. J. Sci. 76, 552-556 
Moleman M., Van Heel M. C. V., Van Weeren P. R., Black W. (2006) Hoof growth between two shoeing sessions leads to a substantial increase of the moment about the distal, but not the proximal, interphalangeal joint. Equine Vet. J. 38, 170-174

Morrison S. (2015). Hoof capsule distortion and its relationship to foot lameness. Retrieved from http://www.roodandriddle.com/ hoofcapsuledistortion.html

O'Grady S. E., Poupard D. A. (2001) Physiological horseshoeing: an overview. Equine Vet. Educ. 13, 330-334

O'Grady S. E., Poupard D. A. (2003) Proper physiologic horseshoeing. Vet. Clin. North Am. Equine Pract. 19, 333-351

O'Grady S. E. (2008) Basic Farriery for the performance horse. Vet. Clin. North Am. Equine Pract. 24, 203-218

Page B. T., Hagen T. L. (2002) Breakover of the hoof and its effect on structures and forces within the foot. J. Equine Vet. Sci. 22, 258-264

Parks A. (2003) Form and function of the equine digit. Vet. Clin. North Am. Equine Pract. 19, 285-307

Perreaux B. T., Hagen T. L. (2002) Observations of asymmetrical horses. The Farrier 22, 258-264

Pollitt C. C. (2008) Equine laminitis current concepts. Publication No. 08/062, Project No. RIRDC UQ-1 18A. Queensland- Australia, 55-60

Redden R. F. (1997) Shoeing the laminitc horse. In: Proceedings AAEP Congress, 356-359. Redden RFA. (2003) Hoof capsule distortion: understanding the mechanisms as a basis for rational management. Vet. Clin. North Am. Equine Pract. 19, 443-462

Riemersma D. J., Van Den Bogert A. J., Jansen M. O., Schamhardt H. C. (1996) Influence of showing on ground reaction forces and tendon strains in the forelimb of ponies. Equine Vet. J. 28, 126-132

Stashak T. S., Hill C., Klimesh R., Ovnick G. (2002) Trimming and shoeing for balance and soundness. In: Stashak TS, editor. Adams' Lameness in horses, Philadelphia: Lippincott Williams \& Wilkins, 1081-1142

Turner T. A. (1986) Navicular disease management: shoeing principles. In Proceedings. 32nd Annu. Conv. Am. Assoc. Equine Practnr. 625-633

Turner T. A., Stork C. (1988) Hoof abnormalities and their relation to lameness. In Proceedings. 34th Annu. Conv. Am. Assoc. Equine Practnr. 293-297

Werpy N. M., Denoix J. M., Mcllwraith C. W., Frisbie D. D. (2013) Comparison between standard ultrasonography, angle contrast ultrasonography, and magnetic resonance imaging characteristics of the normal equine proximal suspensory ligament. Vet. Radiol. Ultrasound 54, 536-547

Wilson A., McGuigan P., Pardoe C. (2001) The biomechanical effect of wedged, eggbar, and extension shoes in sound and lame horses. In: Proceedings AAEP Congress, 339-343

Erweiterte Zusammenfassung

\section{Veränderungen der Hufkapsel und radiographische Messungen der Vordergliedmaßen von Pferden der Ras- se Mangalarga Marchador in Training}

Lahmheiten, die auf Hufprobleme zurückzuführen sind, sind gängig bei Sport- und Freizeitpferden. Klinische Studien haben die Wichtigkeit verdeutlicht, dass Hufkonformation und Hufbalance Risikofaktoren für Muskulatur- und Skelettschädigungen sind. Die Form des Hufs beeinflusst dessen biomechanische Funktion und es gibt Hufformen, bei denen der Verdacht besteht, dass sie ein veranlagter Faktor für
Lahmheiten sind. Einige Autoren konnten schon zeigen, dass durch Trachtenerhöhung und eine geringere Belastung des Fesselträgers durch Erhöhung der Hufspitze eine erhöhte Belastung des Fesselträgers verursacht wird. Andere Studien haben auch schon dargestellt, dass das Hufwachstum zwischen zwei Hufbehandlungen mit einem Intervall von 8 Wochen zu einer Vergrößerung des distalen Interphalangealgelenks führt.

Die Hufe der Pferde der Rasse Mangalarga Marchador werden gewöhnlicherweise flach gehalten, um ihre typische Gangart, die Marcha, zu optimieren. Der Effekt dieses Hufbeschnitts hat in der Vergangenheit zu einer intensiven Diskussion geführt, da die tiefen Trachten und rückwärts gebrochene Krongelenk-Hufachsen zu einer Veränderung Hufkapsel führen. Pferde mit niedrigen Trachten und langen Hufspitzen tendieren dazu, die Hufspitzen zuerst aufzusetzen. Danach, während der Körper sich über die Gliedmaße bewegt, fußen die Trachten, während das Fesselgelenk sich nach unten bewegt. In der Folge kommt es zu einer Mehrbelastung des Fesselträgers. Auch wurde bei Rennpferden eine Verbindung zwischen niedrigen Trachten und katastrophalen Veränderungen des Aufhängeapparates dargelegt. Flache Hufe bei Pferden der Rasse Mangalarga Marchador können zum Ungleichgewicht der Hufe führen, was stressbedingte GröBenveränderungen des Fesselträgers bewirkt. Basierend auf dem Verdacht, dass dies zu radiographischen Veränderungen in den Hufen führen könnte, wurde bei im Training stehenden Pferden der Rasse Mangalarga Marchador radiographische Messungen der Hufe der Vordergliedmaße durchgeführt und die Korrelation dieser mit der Schnittfläche des Fesselträgerursprungs bestimmt.

Es wurden zwei Stuten und 18 Wallache im Alter zwischen 3 und 10 Jahren $(5,8 \pm 2,7$ Jahre) untersucht. Beide Vordergliedmaßen wurden radiographisch in Aufnahmerichtung latero-medial untersucht und an jedem Huf wurden mit Hilfe des Metron Hoof Promit-Programms 14 verschiedene Messungen vorgenommen. Zur Bestimmung der Schnittfläche des Fesselträgerursprungs wurden an der belasteten Gliedmaßeanhand sonographischer Standardtechnik Aufnahmen in Abständen von 4 und $8 \mathrm{~cm}$ vom Os carpi accessorium erstellt. Die Korrelation zwischen den Huf- und Fesselträgervariabeln wurde mit dem Pearson-Test analysiert $(P<0.05)$.

Alle Pferde wiesen nach hinten gebrochene Krongelenk-Hufachsen auf. Bei 59\% wurden die Trachten als niedrig beurteilt und zeigten so ein erhötes Risiko eine Lahmheit zu entwickeln. Dennoch wurde keine signifikante Korrelation zwischen den Hufmessungen und der Schnitfläche des Fesselträgerursprungs festgestellt $(P>0.05)$. Obwohl die Auswirkungen der flachen Hufe anhand radiographischer Messungen dargestellt werden konnten, wurden in dieser Pferdegruppe keine Veränderungen des Fesselträgers festgestellt.

Schlüsselwörter: Pferd / Orthopädie / niedrige Trachten / toe support / Krongelenk-Hufachse / Fesselträger-Desmitis / Marcha 